\title{
Dominant Groups and State-Making
}

Purely external factors determined the creation of Finland as a distinct political entity. As Edward C. Thaden dryly puts it, 'Finnish autonomy, and even the existence of a Finnish nation, can be considered an incidental byproduct of wars between Sweden and Russia during the eighteenth and at the beginning of the nineteenth centuries'.

Prior to 1809 the mainly Finnish-speaking territories east of the Gulf of Bothnia and north of the Gulf of Finland were an integral part of Sweden. As on the other side of the Gulf of Bothnia, the language of the elites was Swedish. The sea did not separate but rather united the eastern provinces with the hub of the state, and these were more oriented to Stockholm than to each other (see Chapter 4). The south-western region of what later became the Finnish state belonged more or less to the core of the Swedish kingdom, whereas the other regions remained at the periphery. The concept of Finland existed, but it was more a geographical term than a political one. Initially it referred to the southwestern region, which had been strongly linked to the core of the state from the thirteenth century onward. Only later was it extended to cover the Finnishspeaking peripheries, which in the course of the subsequent centuries came under the firm control of the Swedish monarchs. ${ }^{2}$ At the end of the eighteenth century about 15 percent of the total population consisted of Swedish-speakers, most of whom were engaged in farming and fishing on the coastal regions.

The most striking characteristic of Swedish society, in the Finnish regions as well as in the territory making up the present-day Swedish state, was a free peasantry, which constituted the backbone of the social structure. Thanks to class balance in the rural economy, the relations of production were never really feudalised. Moreover, during the eighteenth century the position of the landholding peasants was reinforced markedly. In the double process of increases in peasant property and of enclosures, a foundation was laid for the emergence of a strong market-oriented cultivator class as well as for the internal differentiation of the agricultural population.

1 Thaden 1984, p. 82.

2 Klinge 1982, pp. 23-49; Carlsson 1980.

(C) KONINKLIJKE BRILL NV, LEIDEN, 2019 | DOI:10.1163/9789004386174_003

This is an open access chapter distributed under the terms of the CC BY-NC-ND $4_{R} 0$ license lapuro $_{\text {- }} 9789004386174$ 
The freeholders' proprietorship was strengthened, and tenants on crown land were allowed to buy their holdings. Peasants also acquired the right to purchase noble lands. At the same time, common lands were redistributed to the landholders, and the repartition of mixed strips and fields into larger shares was started. ${ }^{3}$

The extensiveness of peasant property in the Swedish kingdom strongly suggests that the dominance of the nobility was based less on landownership than on its central position in the bureaucracy - particularly when Sweden is compared to Eastern and Central Europe. By contemporary standards, Sweden was administered effectively, and the surplus from peasant producers was extracted indirectly, rather than directly by a land-controlling nobility. Even in southwestern Finland, that is, in the Finnish-speaking region where manorial relationships were by far the most widespread, nobles and other gentlemen owned only one-fifth of the complete farms (in Swedish, mantal) at the beginning of the nineteenth century. 5

The comparatively strong position of the peasantry was reflected in the political system. The four-chamber Swedish Diet was unique in Europe in that it included a separate Peasant Estate alongside the hereditary nobility, the occupational clergy, and the burghers - although the Peasant Estate did remain inferior to the other three chambers.

In 1809 eight eastern counties were separated from Sweden and incorporated into the Russian Empire. Although this area was populated mainly by Finnish-speakers, the new border was drawn not on linguistic lines but on strategic ones. In 1807 at Tilsit, the Russian tsar Alexander I had agreed on zones of influence with Napoleon. As a consequence Russia conquered Finland, a territory important for the defence of St. Petersburg, in 1808-9. ${ }^{6}$ One century earlier Peter the Great had won Estland, Livland, and the regions surrounding

3 Østerud 1978a, pp. 130-6. One indication of the deep roots of peasant freeholding in Sweden is that the enclosures furthered independent family farming, rather than leading to a reduction in peasant land, as was the case in England. The Swedish enclosures were initiated by the state and were not linked to the agricultural revolution but preceded it (ibid., pp. 1449).

4 Mäkelä and Viikari 1977, pp. 166-7.

5 Landownership by the nobles and other gentlemen is measured by combining two percentages for the years 1805-7: the proportion of mantal cultivated by tenant farmers in Finland Proper, Satakunta, Häme, and Uusimaa (Jutikkala 1939, 39), and the proportion held by manorial demesnes in the same regions (Jutikkala 1932, pp. 74-82). The percentages - which are not fully comparable - are 16.4 and 3.4 , respectively.

6 Tommila 1984, pp. 7-12, 54; Klinge 1980a, pp. 38-9. 


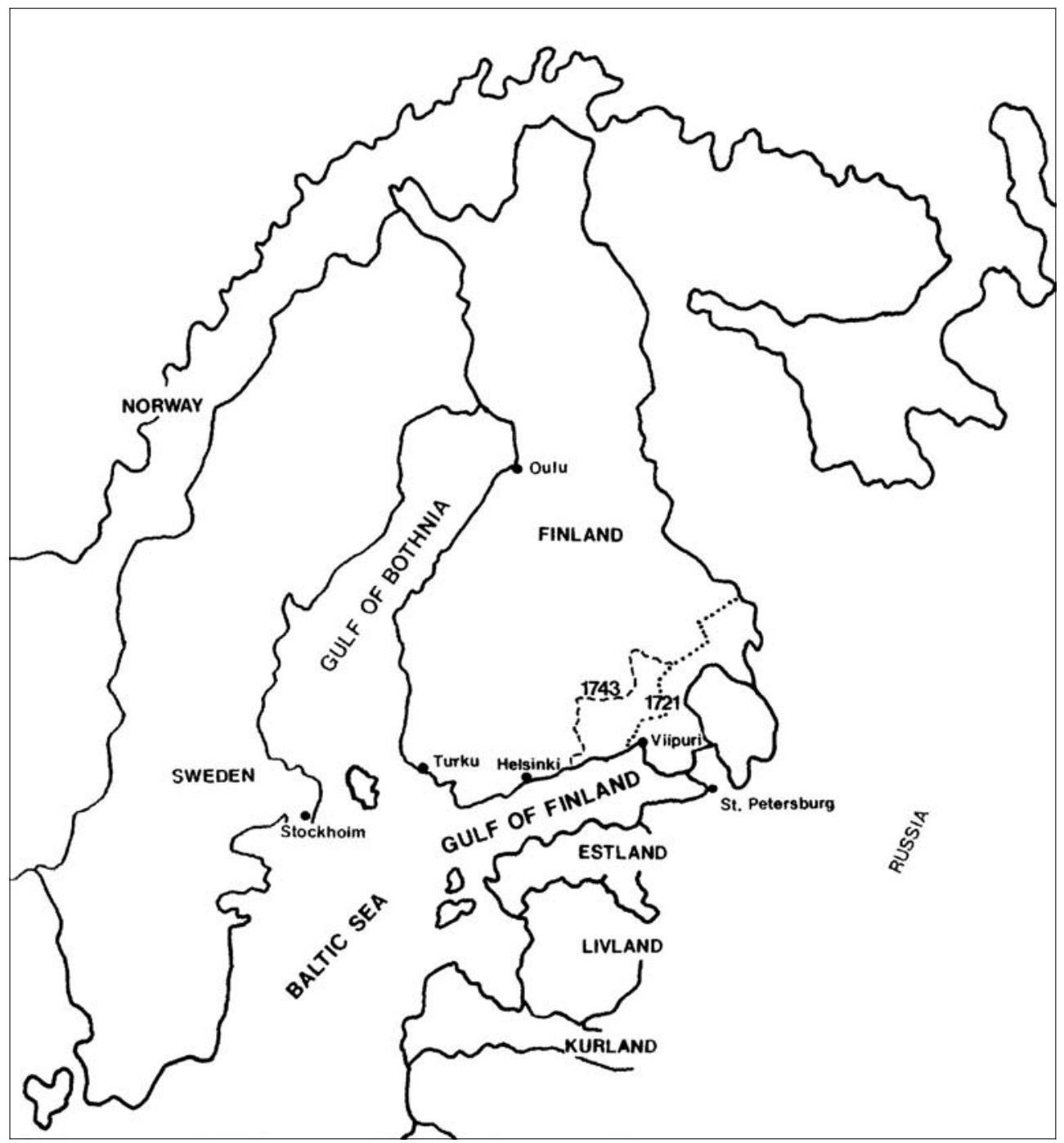

MAP 1 Finland, the Baltic Provinces of Russia, and Scandinavia in the nineteenth century (including the border between Sweden and Russia in 1721 and 1743)

the bottom of the Gulf of Finland from Sweden and established his new capital, St. Petersburg, in the newly acquired territories (see Map 1). From that time on, the protection of the new capital was of primary importance for Russia. During the eighteenth century, moreover, Sweden gradually lost her position as a great power. The conquest of Finland by Russia was the final phase in the shift in the balance of power between these two established members of the European state system. 
Swedish sovereignty in the eastern counties ended in September 1809 with the Treaty of Hamina (in Swedish, Fredrikshamn), and the conquest was confirmed at the Congress of Vienna in 1815. The laws and privileges enjoyed hitherto by the people of the conquered territory were to remain unchanged under Russian rule. This was not exceptional: earlier Peter the Great had coopted the established institutional structure in annexed regions. The pacification measures implemented in Finland in 1809 were similar to those adopted in the Baltic Provinces in 1710. The highest local authority was a Russian governor general. The local administration continued to operate as before, but under the surveillance of the governor general's office. ${ }^{7}$ In the Finnish case, although there was no prior administrative authority covering the entire region, common administrative practices had evolved during the centuries of Swedish rule. These were strictly observed in the new political environment. As early as March 1809 the tsar met with the assembled Finnish estates in the cathedral city of Porvoo (Borgå) and declared his intention to make Finland an imperial grand duchy, a separate entity in governmental, financial, and religious affairs.

Alexander's interest in experiments with political and social reform had an influence on the rights granted to the Finns. He believed that Russia had much to learn from the institutional systems then prevailing in Russia's western borderlands. But foreign-policy considerations were still more important. Because of wars with Sweden, Turkey, and France and, in a broader perspective, because of Sweden's continuing military power, which allowed it to challenge his control of Finland, it seemed imperative to tie the new region to the central government by transferring the loyalties of the local elite to the new sovereign. This had occurred in the Baltic Provinces, and it was the goal in Finland. ${ }^{8}$ 'The imperial policy of autonomy rested on the assumption that political loyalty and orthodoxy in the northwestern border zone could be best guaranteed through the employment of local elites and local traditions. ${ }^{9}$

The goal was pursued by maintaining and even extending privileges, by building a central administration, and by creating a Finnish counterpart of the Swedish four-curia Diet. Among the institutions that were to remain unchanged were the fundamental laws, the Lutheran religion, and corporate privileges. Furthermore, the Finns were not subject to conscription, but they did become eligible for civil and military office in the empire (whereas Russians were not eligible for Finnish posts). The grand duchy had a separate budget and retained its own revenues. The local university in Turku (Åbo), which was

7 Jussila 1981, p. 32; Schweitzer 1984, pp. 202, 203.

8 Thaden 1981b, pp. 15-17; Thaden 1984, pp. 3, 6o-1, 231-2.

9 Selleck 1961, p. 5 . 
later moved to Helsinki (Helsingfors), was given considerable privileges. Finland formed a separate customs area in the Russian foreign trade system. In economic affairs, only tariffs, trade relations with foreign countries, and some features of monetary policy were initially placed under Russian jurisdiction. The traditional administrative units - the counties and the communes - were retained, but they were integrated into a uniform domestic administration. As a further sign of favour, the south-western areas of Karelia around the city of Viipuri (Viborg), annexed by Russia in 1721 and 1743 (see Map 1), were united with the grand duchy in 1812 .

From 1816 the highest domestic authority was the Senate. Its Economic Department served as the supreme administrative council, and its Judicial Department as the supreme court. The members were recruited primarily from the professional civil and judicial service. The Senate was chaired by the governor general, who was the highest official in Finland and commander-inchief of the Russian troops stationed in the country. In St. Petersburg, Finnish matters were prepared and presented by the Committee for Finnish Affairs (between 1826 and 1857, the State Secretariat for Finnish Affairs), headed at first by a state secretary, and from 1834 on by a minister state secretary who figured among the ministers of the empire. Significantly, Finnish affairs were presented directly to the emperor, and the country was not subordinated to the central, ministerial government of Russia. ${ }^{10}$

The meaning of Finland's new position was far from self-evident at the outset. Its true importance and also a number of its institutional forms were established, especially in the first decades of the grand duchy, only through continued and determined efforts by Finnish leaders, for whom the consolidation of Finland's separate status remained a constant preoccupation. ${ }^{11}$ The basis that made this work possible was laid in 1809 and the next few years, during which time Finland acquired for the first time a politically distinct status. Militarily its position was more secure than under Swedish rule, and personally members of the upper echelons of the administration had access to new offices under improved conditions. ${ }^{12}$ Among all Russia's nineteenth-century borderlands, only Congress Poland enjoyed greater autonomy, and that was only until the insurrection of $183^{\circ}-1$.

The various initial measures rapidly produced the desired results. Nearly all important institutional and Swedish-speaking elites made public declarations of loyalty and gratitude, and organisation and recruitment for the new central

\footnotetext{
$10 \quad$ Jussila 1985 , pp. $63,66$.

11 Schweitzer 1984, pp. 201-9; Jussila 1984, pp. 97-8.

12 Selleck 1961, pp. 35-7; Tommila 1984, pp. 51, 58-65, 75-6, 105, 113-31.
} 
administration proceeded apace. For leaders of the Finnish nobility, trained in the Swedish royal service, it was relatively easy to transfer to the tsar personal loyalty developed in an earlier era. ${ }^{13}$ Such shifts of allegiance were quite common during this period, particularly among the nobility. As E.J. Hobsbawm puts it, "Before the "national" era ... various "national" solidarities had only a casual connection, and were not supposed to have any special connection, with obligations to the state centre..14 In 1850, over one-fifth of the adult Finnish male nobility was in the Russian military service. During the entire period of Russian rule, the Imperial Army attracted about 3,300 Finns, mostly from the aristocracy. ${ }^{15}$

From the Russian point of view, the process was facilitated by the constitutional system introduced by the Swedish king, Gustav III, in 1772 and 1789 . The Gustavian constitution presumed the existence of a strong royal executive governing by decree through an administrative hierarchy over which the Diet had very little control. This feature made it easier for the emperor to preserve the fundamental legislation. Moreover, Finland's autonomy was based ultimately on his generosity, not on formal recognition of fundamental laws. Finland never obtained from Alexander I or from his successors formal regulation of its relationship with Russia. The Finnish bureaucratic leaders were well aware that in the autocratic Russian Empire the constitution ultimately rested on a tenuous political balance and that the limitations of monarchy were selfimposed, or rather imposed by considerations of broader policy, over which Finns had no effective control. ${ }^{16}$

In a sense the Gustavian system facilitated cultural separation from Sweden. As a consequence of the war, Sweden's political system and cultural atmosphere changed greatly, and the former mother country became increasingly alien to the Finnish elites. ${ }^{17}$

The fact that the convening of the Diet depended on the monarch was extremely important for the domestic exercise of power. After 1809, the Diet was not summoned until 1863. Subsequently, however, it met at regular intervals. Without a parliament to serve as a public forum for political competition, the bureaucratically organised administration, with the Senate at its top, was needed to carry out important political tasks. And because the tsar remained

\footnotetext{
13 Korhonen 1963, pp. 19o-214; Tommila 1984, pp. 83, 102; Selleck 1961, pp. 40, 42.

14 Hobsbawm 1972, p. 389.

15 Screen 1976, pp. 287-9; Kirby 1979, pp. 6-7.

16 Thaden 1984, 85, 230. Two basic studies are Korhonen 1963 and Jussila 1969; see also Selleck $1961,41,46-47,53$.

17 Klinge 198ob, pp. 13-14.
} 
passive in local affairs, the actual exercise of political leadership devolved in large measure on the bureaucracy, with no clear division of political and administrative functions in the central government. Early nineteenth-century Finland was, in its upper echelons, a thoroughly bureaucratic society. ${ }^{18}$

In sum, then, when Russia created the Finnish polity, the position of the domestic bureaucracy was greatly strengthened. A central administration was built up, but its role was not limited to administrative affairs. By suspending the Diet for nearly half a century, the Russians indirectly endowed the top of the administration with vital political functions.

These arrangements were to change status and power relations among the dominant groups and to create new tensions. Paradoxically, the strengthening of the bureaucracy, which was the stronghold of the nobility, undermined the nobility's traditional position as the first and most powerful estate. Nobility was becoming more a reward than a prerequisite for bureaucratic success. ${ }^{19}$ The erosion was symptomatic of a more general change affecting the dominant groups. In the bureaucratic society of the early nineteenth century, the four estates ceased to reflect adequately social differentiation. The basic social dividing line came to separate the 'gentry' from the masses. The bureaucracy constituted the core of the gentry (in Swedish, ståndspersoner; in Finnish, sääty(äiset). In Swedish usage, the concept of the gentry initially referred to the nobility, the clergy, and their social equals. Later the term other gentry was used to refer to commoners who had entered the military and bureaucratic ranks and to any teachers or professionals who did not fall into the traditional 'learned estate' of the clergy. The gentry revolved around the civil service, which had an internal hierarchy and an official system of ranks. Ultimately the concept came to refer to a social identity recognised more by custom than by law. The gentry pattern included exposure to higher education, employment in the higher levels of the administration, personal association with other members of the gentry, an appropriate standard of living, and use of the Swedish language, which dominated all public services, higher education, and public life. In other words, the gentry was a status group in the Weberian sense. ${ }^{20}$

The existence of this status group is an indication of the stability that prevailed in the bureaucratic society of the time. Business and industrial activity were also under firm administrative control. The domestic government was the main source of commercial funds for business, and only the state could

\footnotetext{
18 Selleck 1961, pp. 25-6, 53-4; Wirilander 1974, pp. 105-6, 116, 12 .

19 Jutikkala 1956, p. 124; Selleck 1961, pp. 25-26.

20 Selleck 1961, pp. 21-5; Wirilander 1974, pp. 33-6, 105-41, 153-9, 179-82, 409; Weber 1968, pp. $305^{-7}, 935^{-8}$.
} 
TABLE 1 Percentage distribution of Finnish population by industry, 1820-1920

\begin{tabular}{lccc}
\hline Sector & $\mathbf{1 8 2 0}$ & $\mathbf{1 8 7 0}$ & $\mathbf{1 9 2 0}$ \\
\hline Agriculture and forestry & $88 \%$ & $83 \%$ & $71 \%$ \\
Industry & 4 & 6 & 15 \\
Trade and communications & 4 & 5 & 11 \\
Unknown & 4 & 6 & 3 \\
$\quad$ Total & $100 \%$ & $100 \%$ & $100 \%$ \\
$\quad$ (thousands) & 1,178 & 1,766 & 3,105 \\
\hline
\end{tabular}

SOURCE: P. MANNINEN 1976, 81

create an adequate infrastructure. The character of the social structure helped to preserve social tranquillity. Nearly nine-tenths of the population worked in agriculture (see Table 1), and the agrarian population was made up mainly of landowning peasants and crofters (see Table 4, p. 43). Only the former had a recognised position in the political system, but in many cases the economic positions of the two groups were very much alike. The agrarian proletariat, in contrast, found itself under strict control owing to the hiring-out obligation and other regulations. ${ }^{21}$

Consequently, during this period the only visible social tension resulted not from challenges by subordinated groups but from the increased power and authority of the bureaucracy. This is a central point in Roberta Selleck's study of the Finnish political discussion during the half-century preceding the reconvening of the Diet in $1863 .{ }^{22}$ Besides the civil hierarchy, the other main elite section in the gentry consisted of the clerical and academic groups. With the strengthening of the bureaucracy, their institutional position was slowly eroded, leading ultimately to dissatisfaction with and opposition to the civil hierarchy.

The Lutheran church and the national university were vested with powers of internal self-government and performed important political functions. The church, through its parish congregations, was responsible for local government in rural areas, as well as for public education - not only the basic instruction in literacy required of all Lutheran communicants, but also the secondary system

\footnotetext{
21 Myllyntaus 1981, p. 178.

22 Selleck 1961.
} 
leading up to the university. There was a close link between the two institutions: both scholars and practising clerics made up the church elite. ${ }^{23}$

Recruitment patterns for the clergy and academic groups were similar and differed from those for the civil hierarchy. Just as there were family dynasties within the bureaucracy, so too was there much clerical-academic self- and inter-recruitment. Another peculiarity was the continuing entry into these groups by people from outside the gentry as a whole. The small flow of the sons of the independent peasantry and the petty bourgeoisie into (lower) church and university posts represented the only regular form of social mobility into the gentry during this period. ${ }^{24}$

The creation of a local bureaucratic hierarchy following the events of $1808-9$ reduced the relative social status of the clerical and scholarly elites. The traditional academic emphasis on a broad classical education conflicted with the bureaucratic view that the university should provide vocational training for public service. ${ }^{25}$ More important, because the church and university shaped public attitudes, not least of all through the educational system, bureaucratic leaders had to make use of the Second Estate in their efforts to maintain the precarious balance of imperial policy. These bureaucratic leaders thus eagerly claimed the right to exercise authoritative control based on their capacity to defend autonomy through a combination of rigid legalism, diplomacy, and strategic compromise. 'While it was generally sufficient to secure passive obedience from other social groups, the clerical and teaching personnel were required to play an active part in the execution of government policy by assisting in the control of public opinion.'26 This was particularly important, at this time when public discussion was limited by official controls and the Diet did not convene, because the university provided virtually the only forum of debate outside the upper levels of the bureaucracy itself.

23 The institutional connections were gradually severed after 1809, but church and university men, sharing a similar educational background and a similar professional interest in the educational process, maintained close contacts even after formal separation (Selleck 1961, pp. 27-9; cf. Wirilander 1974, pp. 256-8, 329-35).

24 Waris 1940, pp. 216, 221-7; Selleck 1961, pp. 25, 29-31. Cf. Wirilander 1974, pp. 201-34, 351-5.

25 As training for the civil service became more important, the university curriculum could not be left in the hands of clergymen and scholars to the extent it had been before. Civil service training had been assigned to the university in the previous century, but a decisive move toward the dominance of bureaucratic considerations occurred after 1810 (Selleck 1961, pp. 74-7; cf. Tommila 1984, p. 132; and Wirilander 1974, pp. 234, 313, 336, 338, 344-5, 35 o, 36o-3, 366). 
For the members of the Second Estate, and especially for their leaders in the academic community, these processes implied a loss of freedom of action. Against various threats to their existence as an autonomous social corporation, politically conscious members of the academic community slowly began to assert alternative claims to status and authority:

As institutional criticism of a liberal nature was prevented by censorship, these claims were expressed primarily in terms of cultural values. General education was opposed to routine administrative skill, and the capacity to contact the depths of the nation was described as more important than the ability to negotiate a defense of legal autonomy. ${ }^{27}$

To conclude, the creation of a separate Finnish polity did not evoke open social conflicts in the early nineteenth century. It did not change the relations between the rulers and the population, as had happened in the early European states; the earlier system of domination was preserved. But the change was significant for the Finnish elites. For the first time they were tied to each other through a domestic administration. The process of state-making, which was shaped above all by the country's dependent position, changed the relations between the elites and generated tension among them. As Selleck points out, ${ }^{28}$ the very structure of Finland's autonomy tended to deflect frustrations arising out of Finno-Russian relations toward domestic targets, hastening the development of opposition within the ranks of the gentry - opposition not to the empire as such but rather to the local, governing elite of the grand duchy. This institutional tension played a part in the rise of the national movement from the 1840 os on (see Chapter 5), and it was amplified and altered in the late nineteenth century as a consequence of the capitalist transformation.

\section{Economic Integration}

The early European national states grew up along with capitalism. In these countries, state-making and the development of capitalism were so closely intertwined that it is hard to distinguish their effects. In the Finnish case the relationship is much less problematic. Because the Finnish polity was created by external decision, economic consolidation could occur only after Finland had evolved politically. In the earliest phase of economic integration, then,

\footnotetext{
$27 \quad$ Ibid., p. 87.
}

28 Ibid., p. 34 . 
the state played the principal role, and it remained central when the capitalist transformation gave further momentum to the process.

Before the 1840s, the efforts of the state were directed more to maintaining the status quo than to creating an integrated economic unit. Industrial development was restrained by mercantilist restrictions, and the surplus extracted from the peasants provided the fiscal basis for nearly all the operations of the state. The largest public expenditure item was administration. ${ }^{29}$ Under this passive policy a national market emerged rather slowly. There were agricultural regions of both over- and underproduction, but only weak commercial links existed between them. Similarly, the national market for industrial products was very modest. 'At present Finnish merchants have more extensive and more active relations with foreign countries than with each other', a geography manual stated in $1827 .{ }^{30}$ Characteristically, the separation of the Finnish counties from Sweden did not lead to a sudden change in commercial relations with the former mother country. Sales to Stockholm of Finnish peasant produce remained important after 1809 in the western regions, and Finland's most important industrial activity, iron fabrication, was almost entirely dependent on Swedish ore until the 186os. Until the 1840s commerce with Sweden resembled domestic trade more than foreign trade. Swedish currency was accepted along with the Russian silver and paper ruble and was even more widely used than the latter currency. ${ }^{31}$ In the east, commercial ties with St. Petersburg were revitalised (see Chapter 4).

Only in the 184 os and 185 os did the state begin to actively support economic consolidation and growth. State revenues were increased in order to promote industry and the construction of the infrastructure, which in turn was supposed to stimulate trade in agricultural products. A monetary reform was carried out, the position of the Bank of Finland (founded in 1811) was reinforced, the tariff and land tax systems were reorganised, financing of industry was facilitated, vocational schools were founded, and the construction of roads and canals gained momentum. In the early 1840 os the country was economically separated from Sweden as earlier tariff privileges were abolished and the Swedish currency was replaced by a domestic one. ${ }^{32}$

29 'Administration' included, above all, the maintenance of (former) officers in the army, abolished when the grand duchy was founded, as well as the maintenance of a small permanent detachment (Myllyntaus 1980, pp. 362-3).

30 Quoted in Mauranen 1980, p. 448.

31 Myllyntaus 1980, pp. 340, 347-8; Schybergson 1980a, pp. 412, 420-1; Schybergson 198ob, p. 451 .

32 Myllyntaus 198o, pp. 338, 342, 353, 355, 358, 365; Schybergson 198oa, p. 432; Schybergson 198ob, p. 457; Mauranen 198o, p. 449 . 
The final steps in the repeal of mercantilist restrictions and in the construction of a national economy were taken between the late 185 os and the late 1870 os. The process was accelerated by the crisis of the autocracy following the Crimean War and by the added strength of the domestic bourgeoisie and other interest groups. By revealing both the economic and military backwardness of the Russian autocracy, the war made internal reforms urgent and directed governmental attention to the loyalty of national minorities. To this end Alexander II, in 1856, initiated a liberal policy of reform in socially tranquil Finland. Gradually, however, this policy led to a crisis, because the established practices of consultation and administrative decree could no longer be employed without consultation with the four Finnish estates. Increasing Finnish demands finally brought the tsar to agree to the resumption and regularisation of Parliament from 1863 on - in the middle of the Polish crisis - and the basic economic legislation was revised. ${ }^{33}$ By the end of the 1870 a separate Finnish currency had been introduced, all industries and trades freed from restrictions, the craft system and limitations on the free movement of labour abolished, active railway construction initiated, and the local administration modernised.

Of decisive importance, however, were the closing decades of the last century. Gross domestic product increased fivefold between 186o and 1913, with the 189 os the period of most rapid growth. The growth rate was one of the fastest in Europe. At the same time, the share of industry and construction in the gross domestic product (GDP) increased from 13 to 25 percent, and the share of the primary sector fell from 65 to 47 percent. Self-financing played an important role in the growth of GDP. ${ }^{34}$ Agriculture was linked to the rapidly expanding market, the main indication being the changeover from traditional arable cultivation to the much more commercial occupation of stock-raising. The land tax was replaced by various indirect taxes, mainly tariffs, as the main source of state revenue. In state expenditure, the construction of the infrastructure and the provision of social services, notably investments in railways and in education, came to predominate along with the administrative expenditures. ${ }^{35}$

In this way the main obstacles to capitalist transformation were removed that is, the state itself began to acquire capitalist features. It no longer merely collected and distributed the surplus produce of the peasantry, as in the early nineteenth century. It now began to develop functions involved in the repro-

33 Suni 1979, pp. 59-63, 100-4; Seileck 1961, pp. 178-9.

34 Hjerppe and Pihkala 1977, p. 6o; Hjerppe, Peltonen, and Pihkala 1984, p. 44; A. Kuusterä 1985, pp. 144-5.

Pihkala 1977 . 
duction of the capitalist mode of production. ${ }^{36}$ The state had proceeded from controlling economic activity to promoting the process of accumulation both by establishing the legal and institutional framework conducive to growth and by carrying out economic activity. Thus a political unit that had been created by an external decision gradually became economically integrated.

This transformation was greatly accelerated by Finland's links to the international economic system. ${ }^{37}$ Actually, as Iván T. Berend and György Ránki have pointed out - and as the importance of tariffs in state revenue makes clear in the Finnish case - it is just at the intersection of domestic and international forces that the state played its part in the capitalist transformation of the European peripheries and prepared the periphery in question to face the challenge of the industrialised West. ${ }^{38}$ By the middle of the century, the industrial revolution in Western Europe had created a capitalist market of a type that had never existed before, with a pulling power that attracted whatever food and raw material the world could produce and that could transform backward agrarian regions within a few decades. ${ }^{39}$ Finland was one of these regions, and wood was the resource exploited. Finland's resource endowment determined its role in the international division of labour, and wood processing became the country's leading industry. Between 1900 and 1909, wood industry products (essentially lumber) accounted for 44 percent of the total value of exports, or as much as 69 percent including forestry and the more advanced paper industry. At the same time, Finnish exports had one of the fastest growth rates among the peripheral countries of Europe, and the value of exports increased fifteenfold from $186 \mathrm{o}$ to 1913. Finland was an 'open economy', the share of exports being twenty to twenty-five percent of the GDP from the 1890 on. ${ }^{40}$

Finland thus began to industrialise at about the same time as other countries in Eastern Europe, and its industrialisation was based on a low value-added export product. Linkages of the sawmill industry with other industrial sectors were modest. Production was based on the abundance of timber and on a cheap labour force. Most of Finland's sawn goods were exported to developed Western countries, notably Great Britain, and the exports were highly vulner-

$36 \quad$ Mäkelä and Viikari 1977, p. 168.

37 The preceding decades had prepared the way, of course. Between 1810 and 1870 the annual increase in the volume of foreign trade averaged two percent (Schybergson 1980b, p. 458).

38 Berend and Ránki 1982, pp. 59-73, 106, 141.

39 See P. Anderson 1974, p. 392; and Berend and Ránki 1982, p. 27.

40 Heikkinen and Hoffman 1982, pp. 6o-70; Pihkala 1969, pp. 63, 74-5; Hirvonen and Hjerppe 1983, p. 32; Berend and Ránki 1982, pp. 114-15. The wood and paper industries accounted at that time for 83 percent of the value of industrial exports, which dominated the export trade. 
able to international price fluctuations. In short, sawn goods were in many respects a staple product similar to those exported by weakly developed and dependent economies. ${ }^{41}$

Finland, however, escaped the so-called staple trap, that is, dependence arising from the dominance of a narrow range of exports based on raw materials. It followed the Scandinavian pattern more closely than that of the EastCentral European agrarian peripheries. ${ }^{42}$ Economic transformation contributed greatly to the process of state-making, and Finland emerged as an economic unit with a territorial division of labour and an autonomous economic core. ${ }^{43}$

What factors provided the initial impetus for Finland's 'self-sustained economic growth', especially from the 188 os and 189 os on? ${ }^{44}$ A comprehensive answer is beyond the scope of this study, but clearly Finland's interface position determined its room for manoeuvre relative to both the Western capitalist market and Russia. First, as far as its Western-oriented export industry was concerned, the linkages of the sawmill industry with other sectors of the economy were the most significant. Activity in many other sectors was financed by the income of the sawmill industry, which was largely domestically owned. ${ }^{45}$ The role of the independent peasantry was decisive in this respect. Finland's earlier history as a part of Sweden had led to the consolidation of a large freeholding peasantry. In the nineteenth century the nonfeudal class structure differentiated Finland from the other Eastern European agrarian peripheries. Unlike elsewhere, in Finland the peasants owned the bulk of the country's main industrial resource, the forests, especially in the most prosperous areas of Finland. Consequently, the rise of the forest industry benefited directly the upper stratum of the peasantry. Their position was quite different from that of other European peasants who owned less forest land and who did not experience the enormous rise in the price of land that occurred in Finland. Even compared to Sweden there was a clear difference ${ }^{46}$ A symbiotic relationship arose between farming, forestry, and the forest industry that enabled the spread of forest incomes to a large number of landowners, contributed to the changeover to stock-raising, increased purchasing power in the countryside, and stimulated

\footnotetext{
41 Hoffman 1980, pp. 110-12, 163-5, 173-4; Ahvenainen 1984, pp. 286-96. See also Berend and Ránki 1982, pp. 116-35.

42 Alestalo and Kuhnle 1987, pp. 12-18; Berend and Ránki 1982.

43 See Heikkinen and Hoffman 1982, pp. 82-7; and below, Chapter 4.

44 Heikkinen and Hjerppe 1981, p. 20; Hjerppe, Peltonen and Pihkala 1984, p. 44.

45 Hoffman 1980, p. 175.

46 Ibid.; Ahvenainen 1984, pp. 244-5; Jutikkala 1963, p. 344.
} 
domestic industry. ${ }^{47}$ Agrarian advance was connected with industrial development, and in this industrialisation direct foreign-investment capital played no important role. ${ }^{48}$

Second, compared to Russia, Finland was a developed region. In fact, Finland was one of the few relatively 'overdeveloped' minority regions within the multinational empires of the time. ${ }^{49}$ Although most of the Finnish counties had been peripheral in the Swedish kingdom, their economic and educational levels were above those of Russia. Finland, long aided by considerable tariff privileges, became from the $1870 \mathrm{os}$ on not only an exporter of raw materials to the West but also an exporter of processed products to Russia. Between 1900 and 1909, Russia accounted for 28 percent of the total value of Finnish exports, but its share in the value of industrial exports, excluding sawmill industry products, was 73 percent. The main imports from Russia were grain products. ${ }^{50}$ Exports to Russia, although they lagged behind those to Western Europe in volume, were of primary importance in stimulating manufacturing, for example the metal and the textile industries, which were the largest sectors after the wood industry. Metallurgy and textiles, along with papermaking, had much closer linkages with other industrial sectors than did the sawmill industry. This connection also facilitated economic consolidation in Finland. ${ }^{51}$

47 Hoffman 1980, pp. 170-2, 174-5; Soininen 1982, pp. 28, 47-50. Cf. Heikkinen and Hjerppe 1981, p. 22.

48 Hjerppe, Peltonen and Pihkala 1984, p. 45. Foreign loans were of significance, however, for example in the forest industry and in railway construction.

49 Only Bohemia, Croatia, and the Russian partition of Poland seem similar in this respect (Nairn 1977, pp. 185-7; Kiernan 1976, p. 120; Berend and Ránki 1982, pp. 107-8).

$50 \quad$ Pihkala 1969, pp. 74-5; Heikkinen and Hoffman 1982, pp. 67-70; Rasila 1982a, pp. 96-9.

$5^{1} \quad$ Preferential tariff treatment in Russia had already helped the Finnish textile and metal industries in the early nineteenth century (Schybergson 1973, p. 59), but new tariffs, adopted simultaneously with the other post-Crimean War reforms in 1859, paved the way for the rapid and favourable development of trade. Several Finnish industries gained a highly advantageous position as compared with industries in Western European competitor countries. The cotton industry became the first modern manufacturing industry in Finland, and before 1850 about 75 percent of its production went to Russia (Schybergson 1980a, pp. 416-17). Similarly, the iron industry exported the bulk of its output to Russia and continuously increased the production of refined iron products as a share of total output. Russia also became the main market for the paper industry. In 1885 , however, the Russian tariffs were readjusted, and Finland lost much of its relative advantage vis-à-vis Western countries. The textile industry had to reorient its production to the domestic market, and the export of certain processed products became unprofitable. In other respects, though, the new tariffs had no major negative impact (Hjerppe 1979, p. 131). Particularly in the 188 os, economic integration proceeded as a consequence of the consolidation of the domestic market. In this decade industrial and other domestic production was clearly 
Finland's role in the emerging international division of labour cannot be explained solely by its interface position or natural resource endowment: of key importance was the continuously increasing demand for wood on the world market. The interface perspective does, however, throw light on those structures through which international market pressures were transmitted to Finland, and it is therefore essential for understanding the process of economic integration. Thanks to its 'Swedish' social structure, Finland was able to reduce the dangers arising from dependence on the export of a single product to the Western market. Moreover, the fact that Finland was 'overdeveloped' in relation to the mother country was decisive for exploiting the Russian connection. Given this constellation of domestic and international forces, the state could successfully operate to strengthen Finland's position both internally and externally.

\section{3}

\section{The Late Nineteenth Century}

During the latter half of the century, the capitalist transformation altered substantially the tensions that had emerged between the civil bureaucracy and the academic and clerical groups. Most important, the central role of the state in the process of industrialisation produced close connections between the bureaucratic elite and the bourgeoisie proper, which was made up of a growing number of owners and controllers of means of production. In economic policy the interests of industry were generally given priority over those of agriculture. ${ }^{52}$ One major early indication of this partiality was corporate consultation in economic planning, as governmental, industrial, and commercial interests were reconciled in large economic commissions that laid the foundation for the great reforms of the 185 os and 186 os. There was also considerable interrecruitment between the bureaucratic and the commercial-industrial elites. ${ }^{53}$

less dependent on foreign trade than previously (Hjerppe 1979, p. 27). Increasingly, the textile, machine, and other industries began to find outlets for their products in the domestic market (Hjerppe 1979, pp. 35, 131; Hjerppe 1981, p. 223; Hoffman 198o, pp. 34, 92, 116, 1745; Heikkinen 1981, pp. 417-18). In a period in which domestic grain production was going through a profound crisis and agriculture was changing over to stock-raising, grain imports from Russia facilitated structural transformation. These imports were also advantageous to industry because they made it possible to keep wages low (Myllyntaus 198o, p. 349; Pipping 1969, p. 23).

52 Harmaja 1933, pp. 213, 219, 221. Cf. Pipping 1969, p. 23.

53 The economic elite came primarily from the gentry. The upper stratum of the burghers, i.e., the owners and managers of the large commercial houses, played a central role, espe- 
Besides the bourgeoisie, another emerging group was the landowning and Finnish-speaking peasantry, whose wealthiest stratum was on a par with the landed gentry. Rapid economic rise was accompanied by political and cultural consolidation when the Diet was reconvened in 1863 and local government reformed in 1865 (see Chapter 3). In the late nineteenth century this group often allied itself with the clergy, then on the decline. At that time the educational system was divorced from the church, and local government from local parish administration. The decline of the clergy and its coalition with the peasantry are reflected in recruitment patterns. The sons of the gentry increasingly rejected clerical careers, and interrecruitment between academic and clerical groups decreased. Yet at the same time, socially mobile peasant sons joined the ranks of the clergy, which became the first gentry group with a Finnishspeaking majority. ${ }^{54}$ As a church historian states, 'When the clergy realized that its hold on a large portion of the educated class was lost, it tried to find a closer connection with the peasant folk. 55

With the formation of two clusters among the dominant groups, earlier tensions were altered. The division emerged in the last decades of the century, after regular parliamentary meetings had begun to breathe new life into dormant political life. On one side were the bureaucracy and the bourgeoisie with their Swedish culture, on the other the church and the Finnish-speaking peasantry. In the Parliament the main cleavage was between most of the nobles and the burghers on the one hand, and the clergy and the independent peasantry on the other.

The economic tensions between the new bourgeoisie and the landowners were similar to those found in Scandinavia, ${ }^{56}$ but in Finland they were reinforced by a cultural cleavage. Not surprisingly, these tensions are important for understanding the social basis of the national movement (Chapter 5); still, the cleavages should not be exaggerated. Economic development was undermining the gentry as a status group, but there was nonetheless a culture common to all dominant groups except the wealthy peasantry. In absolute numbers the gentry was small: in 1870 , for example, it consisted of only 27,000 persons, fam-

cially in the sawmill industry, but the nobility and the bureaucracy produced members of the upper industrial and commercial stratum as well. There was also a movement from business to bureaucracy. Systematic information, however, covers only the period 1810$5^{2}$ (Hoffman 1980, pp. 77-84; A. Kuusterä 1981; Mauranen 1981, pp. 200, 210; Schybergson 1977; Jutikkala 1974, pp. 24-48, 113; Noponen 1964, pp. 34-8; Waris 1940, pp. 258, 260).

55 Juva 196o, p. 359 .

$56 \quad$ Rokkan 1970, pp. 108-9. 
TABLE 2 Percentage distribution of Finnish population by estate, 1890

\section{Estate}

\begin{tabular}{lc} 
Nobility & $0.1 \%$ \\
Clergy & 0.3 \\
Burghers & 3.1 \\
Independent peasantry & 26.1 \\
Others & 70.4 \\
$\quad$ Total & $100.0 \%$ \\
$\quad \mathrm{~N}$ (thousands) & 2,380 \\
\hline
\end{tabular}

SOURCE: ÉLÉMENTS DÉMOGRAPHIQUES

PRINCIPAUX DE LA FINLANDE POUR LES

ANNÉES 1750-1890 1899, 261, 262

ily members included, or 1.5 percent of the total population. ${ }^{57}$ Twenty years later the share was somewhat higher, as may be seen from the first three figures in Table 2. All elites shared a similar background; they were educated at the same university and often knew one another. ${ }^{58}$ And all were unanimous about the need to maintain and reinforce political autonomy. Conflicts between the landowners and the rising bourgeoisie seem to have been comparatively restricted. The landowning peasantry benefited from the leading industrial sector, sawmilling, and over a time a certain community of interests emerged.

These features should also be viewed in the context of the social tranquillity then prevailing. No challenge from below forced the dominant groups to close ranks. Apart from the last decade, the nineteenth century was a period in which internal social conflicts were practically unknown (see Chapter 6) $)^{59}$ and external peace continued uninterrupted. The dominance of the landowning peasantry tended to mask the growth of the rural proletariat, and the urban proletariat increased significantly only in the 18gos. The ultimate guarantee of stability was provided by the empire, even if imperial troops were never needed

$57 \quad$ Wirilander 1974, p. 142.

$5^{8}$ Klinge 1980a, pp. $53,64,66$. The number of students was small, around $600-50$ in the 1870 , and only grew to about 1,250 at the turn of the century (Klinge 1967-8, 2:3, 3:2, 168).

59 The only region of peasant unrest in nineteenth-century Finland was the county of Viipuri. In this region, the so-called Old Finland, which was united with the 'new' Finland in 1812 , Russian nobles had been granted land in the eighteenth century. 
to put down local insurrections, as happened in Poland. Characteristically, only minor readjustments were made in corporate privileges. At the beginning of the twentieth century, Finland had essentially the same political system as it had in 1789 .

A final indication of the growing strength of the local dominant groups and of Finland as a separate political unit was the creation of a national armed force. Up to the 1870 os there was a peacetime Finnish detachment of between 1,60o and 4,50o men. In 1878, after general conscription had been introduced in Russia, the Parliament succeeded in obtaining approval for a separate Finnish army, a concession necessitated by the conflict in the Balkans and the concomitant Russian fear of Swedish intervention. ${ }^{60}$ This army was also raised through general conscription and at full strength never exceeded 5,60o men. ${ }^{61}$ Thus, whereas Alexander I's two other conquests, Bessarabia and Congress Poland, lost their original status in the course of the nineteenth century, Finland succeeded in preserving and even strengthening its original position. ${ }^{62}$

In the last decades of the century, territorial consolidation, centralisation, and differentiation of the instruments of government and economic integration occurred, as did monopolisation of the means of coercion. As to centralisation and the character of governmental institutions, Finland had not only a legal order but also a centralised administrative apparatus subject to this legal order - that is, the bureaucracy. In a word, Finnish leaders were increasingly in charge of, to use Weber's term, a modern state. ${ }^{63}$

6o Suni 1979, p. 98.

61 The rest of the conscripts remained in reserve. Young men were chosen by lot only to the extent necessary to keep the total active force at 5,600 (Lundin 1981, p. 420).

62 Jussila 1984, pp. 99-102; Polvinen 1984, p. 6 o.

63 According to Max Weber, the essential characteristics of the modern state are legal order, bureaucracy, binding authority over a territory, and monopolisation of the legitimate use of coercion (Weber 1968, p. 56; Bendix 196o, pp. 417-18). 